Post print version. Work-related attitudes as antecedents of perceived individual-, unitand organisation-level performance. International Journal of Organizational Analysis. 2017, vol. 25, issue 4, pp. 577-595. The final publication is available at Emerald via https://doi.org/10.1108/IJOA-05-2016-1028.

\title{
WORK-RELATED ATTITUDES AS ANTECEDENTS OF PERCEIVED INDIVIDUAL-, UNIT- AND ORGANISATION-LEVEL PERFORMANCE
}

\section{Author:}

Hanna Salminen, School of Management, University of Tampere, Tampere, Finland Mika Vanhala, School of Business and Management, Lappeenranta University of Technology, Lappeenranta, Finland

Pia Heilmann School of Business and Management, Lappeenranta University of Technology, Lappeenranta, Finland

\begin{abstract}
Purpose: This paper contributes to the debate on employees' subjective performance evaluations by examining how organisational commitment and job satisfaction are related to perceived performance at the individual-, unit- and organisation-level.

Design/methodology/approach: Quantitative survey data were collected from two large corporations in Finland: one operating in the field of information and communications technology (ICT) and the other in the forestry industry. Partial least squares (PLS) method was used for the data analyses.

Findings: Both job satisfaction and organisational commitment had a positive effect on employees' perceived individual-, unit- and organisation-level performance. These effects were strongest at the organisation-level.

Originality/value: To date, limited attention has been paid to perceived individual-, unit- and organisation-level performance as a consequence of organisational commitment and job satisfaction.

Keywords: Organisational commitment, Job satisfaction, Performance, Finland Paper type: Research paper
\end{abstract}




\section{Introduction}

Organisational commitment and job satisfaction have been studied since the beginning of the human relations movement, especially with regard to their influence on employee performance (Meyer et al., 2008; Saari and Judge, 2004). Previous studies have provided evidence that a committed and satisfied employee is also an employee who performs well ( $\mathrm{Fu}$ and Deshpande, 2014; Lee et al., 2010; Riketta, 2002; Ostroff, 1992). However, metaanalyses have typically demonstrated only a modest positive link between organisational commitment and performance (Mathieu and Zajac, 1990; Riketta, 2002, 2008), or between job satisfaction and performance (Iaffaldano and Muchinsky, 1985; Riketta, 2008), possibly because of a rather narrow definition of performance (Ostroff, 1992). In addition, metaanalysis has shown that positive affectivity has an affirmative influence on job performance at the individual level (Kaplan et al., 2009). Some recent studies have used broader concepts, such as job engagement, to capture the physical, cognitive and emotional dimensions of individual energies and their influence on job performance (Rich et al., 2010).

The relationship between work-related attitudes and job performance has received continuing interest from organisational behaviour (OB) scholars (Kaplan et al., 2009), and the strength of this relationship remains under discussion (Schleicher et al., 2015). The majority of previous research into work attitudes and job performance has focused on individual-level job performance; fewer studies have focused on unit-level (Melián-González et al., 2015; Ostroff, 1992; Ryan et al., 1996) or organisation-level performance as a consequence of work-related attitudes (Den Hartog et al., 2013; Conway \& Briner 2012; Harter et al., 2002). This is surprising as most organisations aim to improve the attitudes of their employees in order to improve organisation-level performance (Judge and Kammeyer-Mueller, 2012).

No single theoretical framework exists to explain the link between work-related attitudes and performance in organisations (Furtmueller et al., 2011). Whether work-related attitudes influence performance or vice versa is also debatable. However, more evidence has been found in favour of the former notion (Mullins and Christy, 2016; Judge and KammeyerMueller, 2012; Riketta, 2008). Some studies have relied on the theory of planned behaviour (Ajzen, 1991), which assumes that attitudes influence individual intentions and ultimately serve as predictors of behaviour (Judge and Kammeyer-Mueller, 2012). Other studies have focused on the reciprocal nature of the employee-organisation relationship by using social exchange theory as a theoretical framework (Ostroff, 1992). This is especially the case in many human resource management (HRM) studies, in which HRM practices are expected to influence employee attitudes (for example, job satisfaction and organisational commitment). In turn, employee attitudes are thought to affect employee behaviour (e.g., organisational citizenship behaviour), ultimately affecting performance at the unit and organisational level (Melián-González et al., 2015; Den Hartog et al., 2004; Kinnie and Swart, 2009; Purcell and Hutchinson, 2007; Snape and Redman, 2010). Research into the marketing field has presented a similar causal chain, describing how internal marketing can influence employees' workrelated attitudes, with a subsequent impact on organisational performance (Kanyurhi and Akonkwa, 2016). Some customer service studies have relied on the emotional contagion theory when investigating the relationship between work-related attitudes and job performance; these studies argue that positive emotions can spread across the work environment through social interaction (Netemeyer et al., 2010, p. 532).

Considering that organisations are flatter than before, and that most of the work in today's organisations is organised around teams, it makes sense to investigate how employees evaluate not only their own performance, but also the performance of their unit and organisation. For example, in Finland, 64\% of all employees worked in teams in 2013. Teamwork is particularly common in the ICT sector but other technical fields also reported that over 70\% of their employees worked in teams (Lehto and Sutela, 2014). In this study, 
performance is defined as subjective employee perceptions of performance at the individual-, unit- and organisation-level. The aim of this study is to analyse the relationship of job satisfaction and organisational commitment with employees' perceptions of performance at the individual-, unit- and organisation-level.

\section{Literature Review}

\section{Organisational Commitment and Job Satisfaction}

Employees' loyalty and commitment towards their organisation can been seen as important contributors for an organisation's longevity and performance (Bakker and Schaufeli, 2008). Employee loyalty has been characterised in terms of trust, identification, participation, commitment and attachment. The suggested ways in which employee loyalty may influence performance differ. Examples include reducing turnover, increasing profits, improving work quality, creating innovations and increasing organisational reputation or trust in the team (Guillon and Cezanne, 2014, p. 839.)

An employee with organisational commitment identifies with a particular organisation and its goals and wishes to remain a member. Such employees are emotionally attached to an organisation and believe in its values (Solinger et al., 2008). Because they have a sense of organisational loyalty, committed employees are less likely to engage in work withdrawal, even when they are dissatisfied (Hausknecht et al., 2008). Over the years, understanding of organisational commitment has changed from a one-dimensional (Porter et al., 1974; Cook and Wall, 1980) to a multi-dimensional perspective (Meyer \& Allen 1991). Porter et al. (1974, p. 604) considered organisational commitment to include: "1) a strong belief in and an acceptance of the organisation's goals and values, 2) a willingness to exert considerable effort on behalf of the organisation and 3) a definite desire to maintain organisational membership". Similarly, Cook and Wall (1980) described organisational commitment as consisting of 1) organisational identification, 2) organisational involvement and 3) organisational loyalty. Meyer and Allen (1991) viewed organisational commitment as a three-dimensional construct comprising affective, normative and continuance commitment. Affectively and normatively committed employees feel emotionally attached to their organisation and experience a moral obligation to their employer, respectively, whereas continuance commitment illustrates the calculative aspect of employee commitment towards an organisation (Meyer and Allen, 1991, p. 67; Meyer et al., 2002, p. 21).

Although organisational commitment is closely related to job engagement, it has been argued that it fluctuates less than job engagement over time (Rich et al., 2010, p. 630). There is also evidence that organisational commitment and job satisfaction have a strong positive correlation (Legge, 2005; Porter et al., 1974). This can be partly explained by the fact that job satisfaction measures can include statements regarding an employee's satisfaction with the whole organisation, not merely their own job (Meyer et al., 2002). Nevertheless, organisational commitment and job satisfaction are separate constructs, with organisational commitment considered to be more stable than job satisfaction (Porter et al., 1974; Judge and Kammeyer-Mueller, 2012).

The common characteristic of one-dimensional definitions of organisational commitment and Meyer and Allen's (1991) affective organisational commitment is that they all refer to employees' attitudinal commitment. The attitudinal commitment perspective assumes that employees exchange commitment in return for rewards provided by the organisation (Legge, 2005). The organisational commitment scale used in this study is based on five items taken from the British Organisational Commitment Scale (BOCS) (Cook and Wall, 1980). BOCS, the Organisational Commitment Questionnaire (OCQ) (Mowday et al., 1979) and the Affective Commitment Scale (ACS) (Meyer and Allen, 1991) are among the 
most frequently used attitudinal organisational commitment scales (Mathews \& Shepherd 2002, p. 369). The BOCS scale has demonstrated good reliability and validity in different studies about both professional and non-professional employees (Conway and Briner, 2012, p. 478).

The concept of job satisfaction refers to a state in which employees feel pleasure in their job (Shaikh et al., 2012). Judge and Kammeyer-Mueller (2012, p. 344) define job attitude as "evaluations of one's job that express one's feelings towards, beliefs about and attachment to one's job". In this definition, a job is broadly understood to cover the individual's work, occupation and employer. This definition also highlights both the cognitive and affective aspects of job attitudes (Judge and Kammeyer-Mueller, 2012). The level of job satisfaction is affected by a wide range of variables related to individual, social, cultural, organisational and environmental factors (Mullins and Christy, 2016, p. 251).

Both a global and a facet approach can be used when investigating employee job satisfaction. The global approach refers to employee job satisfaction as a whole, whereas the facet approach focuses on employee satisfaction with different aspects of the job (Saari and Judge, 2004). Situational factors such as supervision, co-workers, promotion, pay and the work itself are important factors in employee job satisfaction (Crossman and Abou-Zaki, 2003). In particular, satisfaction with one's own work is regarded as an important factor indicating overall job satisfaction (Judge and Kammeyer-Mueller, 2012, p. 348). There is also evidence that job satisfaction is positively related to employee life satisfaction (Saari and Judge, 2004, p. 398). The current study investigates employees' satisfaction with their work, manager, organisation, career progression and opportunities for self-development, using measures from a study by Cook et al. (1981).

\section{Performance}

Job performance has been understood as a multi-dimensional concept (Kaplan et al., 2009, p. 163). A distinction is usually made between task performance and contextual performance (Demerouti et al., 2014). The former refers to the performance required by a particular job (in-role performance), whereas the latter describes interpersonal job performance (extra-role performance) or citizenship behaviour, which goes beyond what is required in a job (Demerouti et al., 2014; Riketta, 2002; Yiing and Bin Ahmad, 2009). Other forms of performance have also been studied, including adaptive performance (Sonnentag et al., 2008), withdrawal, counterproductive behaviour and creative (Judge and Kammeyer-Mueller, 2012) or innovative performance (Lee et al., 2010). Recently, safety performance, measured as the prevalence of occupational injuries, has been identified as yet another dimension of job performance (Kaplan et al., 2009, p. 165).

Studies investigating the relationship between work-related attitudes, such as organisational commitment and job satisfaction, and individual-level job performance have relied on self-reported performance data from employees (Crossman and Abou-Zaki, 2003; Schoemmel and Jønsson, 2014), manager evaluations of individual performance (Lee et al., 2010) and objective performance data (Hunter and Thatcher, 2007; Siders et al., 2001).

Subjective performance measures are typically used when objective performance data are not available (Jaramillo et al., 2005). According to one meta-analysis, looking at research over a 25-year period, only 1 out of 51 studies on the relationship between organisational commitment and job performance used objective performance data. The rest of the studies analysed relied on subjective performance data (self-reported data or supervisory ratings) (Jaramillo et al., 2005, p. 706, 708). Performance appraisal refers to procedures such as setting work standards, assessing an employee's actual performance relative to those standards and providing feedback and motivation to outperform (Dessler, 2008). Performance measurements for the individual are often influenced by sector and type of work. For 
example, a study by Furtmueller et al. (2011) demonstrated that performance measurements for financial professionals were based on sales figures, customer satisfaction and the attainment of certain goals. In this study, individual-level performance is measured as perceived in-role performance, focusing on the requirements of the job and the way this can influence the technical core of the company (Kaplan et al., 2009, p. 163).

There is no clear consensus on how unit-level and organisation-level performance should be measured. For example, Dvir and Shenhar (1992) have argued that unit-level performance and success are influenced by both short-term (e.g., profitability, generating orders) and long-term performance measures (generating new opportunities and preparing the infrastructure for the future). In measuring organisation-level performance, both objective performance measures, such as academic achievements based on standardised test scores (Ostroff, 1992) or total profit, market share and volume (Ryan et al., 1996), and subjective performance measures, such as students' satisfaction (Ostroff, 1992) and customer satisfaction (Ryan et al., 1996), have been used. This study, which relies on subjective data when studying employees' perceptions about unit- and organisation-level performance, follows a study by Delaney and Huselid (1996), who examined product quality, customer satisfaction, new product development and market performance. This measuring instrument has also been used to study how restaurant employees perceive unit performance (Den Hartog et al., 2013, p. 1648).

\section{Organisational Commitment and Job Satisfaction as Antecedents of Performance}

Several meta-analyses concerning the relationship between organisational commitment and individual-level job performance have provided evidence that a positive, albeit modest, correlation exists between organisational commitment and individual-level performance (Jaramillo et al., 2005; Mathieu and Zajac, 1990; Meyer et al., 2002). For example, a metaanalysis by Meyer et al. (2002) has demonstrated that affective organisational commitment has a stronger positive correlation with job performance than normative organisational commitment. In addition, their study found that continuance commitment had a negative correlation with job performance (Meyer et al., 2002). Another meta-analysis, conducted by Jaramillo et al. (2005), showed that a positive association between organisational commitment and performance was stronger among salespeople than other employees. In addition, they found that this relationship was stronger in collectivist than in individualistic cultures (Jaramillo et al., 2005, p. 705).

It has also been suggested that more committed employees demonstrate greater extrarole performance than less committed employees (Mathieu and Zajac, 1990). However, Riketta's (2008) meta-analysis of panel studies demonstrated that organisational commitment and job satisfaction had a positive effect on both in-role and extra-role performance. Lee et al. (2010) also found that affective organisational commitment was positively related to both inrole and innovative performance among health care professionals working for an East Asian health care organisation.

Other studies have focused on the relationships between different commitment targets and individual-level performance. For example, in an analysis of the relationship between multiple commitment foci and individual performance, Schoemmel and Jønsson (2014, p. 516), found that employees' affective commitment to their job was more strongly related to performance than affective commitment to the organisation or department. There is also evidence that an employee's commitment to his or her supervisor can predict individual-level performance better than organisational commitment (Becker et al., 1996). Different mediating variables between organisational commitment and job performance have also been studied, such as organisational culture (Yiing and Bin Ahmad, 2009), job experience and perceived stress (Hunter and Thatcher, 2007). For example, a study by Hunter and Thatcher (2007), 
conducted in a large US bank, showed that more committed and experienced employees were better able to channel perceived stress into job performance than less committed or novice employees.

When it comes to the relationship between job satisfaction and individual-level performance, meta-analyses have confirmed the existence of a positive but modest correlation (Judge et al., 2001; Riketta, 2008). Different models have also been used to investigate the relationship between job satisfaction and individual-level performance, including causal, reciprocally related, moderated and non-related models (Judge et al., 2001). For example, a study by Siengthai and Pila-Ngarm (2016, p. 162) into the hotel, resort and banking industry in Thailand has demonstrated that job satisfaction positively moderates the relationship between job redesign and job performance. A study by Schleicher et al. (2015), however, has shown that job attitude strength (JAS) moderates the relationship between job satisfaction and job performance. In other words, those employees who had strong levels of job satisfaction also demonstrated higher levels of job performance (Schleicher et al., 2015, p. 1259).

Although performance can be studied at different levels (Den Hartog et al., 2004), limited attention has been paid to unit- and organisation-level performance as consequences of organisational commitment and job satisfaction. Relatively few studies have investigated the link between work-related attitudes and unit-level (Harter et al., 2002) or organisationlevel performance outcomes (Ostroff, 1992; Ryan et al., 1996). In their meta-analysis, Harter et al. (2002) found evidence that employee job satisfaction and engagement at the businessunit level were positively related to performance outcomes such as customer satisfaction, productivity, profit, turnover and accident rates. Kehoe and Wright (2013) studied employees' group-level perceptions about high-performance HR practices and their influence on employee work-related attitudes and behaviours. They found that positive group-level perceptions about the HR practices used in the organisation were positively associated with an employee's affective organisational commitment, intention to remain in the organisation and citizenship behaviour, but were negatively associated with absenteeism (Kehoe and Wright, 2013, p. 383). Ryan et al.'s (1996) study of different branches within a large US automobile finance company demonstrated that customer satisfaction was related to organisation-level job satisfaction. This, in turn, was positively associated with branch-level performance (Ryan et al., 1996). A study by Ostroff (1992) demonstrated that both job satisfaction and organisational commitment had a strong positive relationship with organisation-level performance in a school environment.

The positive link between work-related attitudes and performance at both the unit- and organisation-level may be due to the fact that the aggregation of performance results at higher levels may mirror the synergies of individual outcomes (Meyer et al., 2008). Shared attitudes at the unit- or organisation-level can be also explained using the attraction-selection-attrition (ASA) model presented by Schneider (1987), which postulates that employee work-related attitudes become similar over time because employees experience the same situational influences in organisations (see Ryan et al., 1996, p. 854). For instance, employees working in the same organisational unit are likely to be influenced by the same situational factors (e.g., customers, supervision and working environment) and social interactions. As a result, employees are likely to demonstrate similar work-related attitudinal responses, which ultimately influence organisation-level performance (Ryan et al., 1996). In the same way, emotional contagion theory has been used to explain how the affective moods of an employee or group of employees can spread through social interaction, either consciously or subconsciously (Netemeyer et al., 2010). For example, a study on retail companies demonstrated that high job satisfaction and performance levels among retail managers were positively related to employee performance (Netemeyer et al., 2010).

Based on the literature review, the following hypotheses were proposed: 
Hypothesis 1a-c: Employees' job satisfaction is positively associated with employees' perceptions of performance at a) the individual-level, b) the unit-level and c) the organisationlevel.

Hypothesis 2a-c: Employees' organisational commitment is positively associated with employees' perceptions of performance at a) the individual level, b) the unit-level and c) the organisation-level.

\section{Data and Methodology \\ Data Collection and Sampling}

The survey data were collected from a total of 715 respondents (representing a $34.3 \%$ response rate) within two large Finnish corporations: an ICT firm and a forestry company. The questionnaire was made available in paper format and in an online version. The majority of the respondents were men $(81.7 \%$ vs. $16.6 \%$ women), although a few respondents failed to provide information about their gender. Over a third (36.1\%) of respondents were in the 31 - to 40-year-old age group, whereas just under a third (31.9\%) were in the 41- to 50-year-old age group. Over a third (37.2\%) had a vocational education, a fifth (22\%) had a higher-level university degree and a fifth $(21.5 \%)$ had a lower-level university degree. Most respondents had worked for their organisation for over 10 years: 11-15 years (13\%), 16-20 years $(9.2 \%)$ and over 20 years $(32.7 \%)$. The majority were employees $(75.9 \%)$ or officials $(15.2 \%)$. Other notable groups were team leaders $(4.2 \%)$ and managers $(2.2 \%)$.

\section{Measures}

All the measures were based on a five-point Likert scale ( $1=$ strongly disagree to $5=$ strongly agree). Organisation-level performance was measured on a scale ranging from " $1=$ very poor" to " $5=$ very good". The items used in the study were adopted from earlier studies. The wording of a few items was modified slightly with the help of company representatives in order to make the questions more appropriate for the studied companies. Scale items are presented in Appendix 1.

Job satisfaction was measured using five items from a study by Cook et al. (1981). These items comprised satisfaction with the manager, job, organisation, career progression and opportunities for development. In this study, the organisational commitment scale was based on five BOCS items (Cook and Wall, 1980), which covered identification (two items), involvement (two items) and loyalty (one item).

Performance was considered to be the individual employee's subjective perceptions of performance at the individual-, unit- and organisation-levels. This approach was adopted for two reasons: 1) the two companies were reluctant to share objective performance data and 2) the intention of the study was to ensure comparability between different kinds of organisational units and organisations. Although perceptual data can introduce limitations through increased measurement error and potential mono-method bias, research has found that measures of perceived performance tend to have a positive correlation with objective measures (Delaney and Huselid, 1996; Robinson and Pearce, 1988). The validity of the subjective perceptions was confirmed by the company representatives.

Individual-level performance was measured using three items. Whereas two items came from Robinson (1996), the third item ("I am satisfied with my work performance compared to employees who do the same kind of job") was created by the researchers and added to make the scale more reliable. Unit-level performance was measured by eight items from Dvir and Shenhar (1992). Organisation-level performance was assessed by six items from Delaney and Huselid (1996). The respondents were asked to compare their organisation's performance with that of other successful organisations in terms of quality of products and services. The 
suitability of the performance measures employed, especially the organisation-level measures, was validated by the companies' representatives. For example, both companies had extensive internal communication practices in place to help respondents make comparisons with other firms.

It is possible that certain personal variables can influence respondents' performance evaluations. We therefore controlled education, employment duration (tenure) and position in the organisation. These measures have also been used as control variables in previous studies into the link between work-related attitudes and performance (cf. Hunter and Thatcher, 2007; Conway and Briner 2012; Siengthai and Pila-Ngarm, 2016).

\section{Data Analysis}

Partial least squares (PLS) was used for the analyses (SmartPLS, version 2.0 M3) for a number of reasons (see e.g., Hair et al., 2012; 2013; 2014). First, our data were not normally distributed and restrictions with the sample size requirements prevented us from using covariance-based structural equation modelling (SEM). Secondly, the complexity of the research models prevented us from using conventional SEM. Finally, our research design was exploratory, aiming to explain the variance of perceived performance. Therefore, PLS is a suitable prediction-oriented estimation method for this case.

The first step in the data analysis was to assess the reliability and validity of the measurement models. The structural model was then used to test the proposed hypotheses.

An ANOVA test was carried out on the ICT industry sample in order to confirm the absence of non-response bias. It was presumed that the last respondents would most closely resemble non-respondents (Armstrong and Overton, 1977). No significant differences were found between early and late respondents. As a result, non-response bias was not considered to be a problem in this study. Because the data relied on self-reporting measures, common method variance may have biased the findings. Harman's one-factor test (Podsakoff et al., 2003) was used to assess this risk. As a result, a principal component analysis incorporating all the items from all the constructs was conducted in order to determine the number of factors needed to account for the variance in all the items, with the largest factor accounting for $29.5 \%$ of the variance. In addition, in line with Podsakoff et al. (2003) and following the procedure suggested by Liang et al. (2008), a measurement model that included one method factor was also tested. In the model, items were allowed to load on both their theoretical constructs and on a common method factor. The loadings on the method factor were substantially lower than the loadings on construct factors. Taken together, these tests suggest that common method bias was unlikely to be a serious concern in this study.

To ensure sufficient variance in the assessments of unit-level performance between respondents from the different units, we performed an analysis of variance (ANOVA) test, following the procedure established by James and Williams (2000). Based on the test, it can be stated that responses from different units are independent and without, for instance, some kind of 'organisational bias' (i.e. there is no variation between units within the organisation). It can therefore be concluded that the differences between assessments of unit-level performance can be accounted for by differences between units.

In order to test the measurement models, internal consistency and discriminant validity were assessed. Construct reliability (CR) and convergent validity measures represent internal consistency. According to the CR test, all the constructs showed a value above the threshold (0.7), as adopted by Bagozzi and Yi (1991) (see Table 1). In order to test for convergent validity, the study examined $\mathrm{CR}$, factor loading and average variance extracted (AVE). First, the loadings of all the items were high and statistically significant. This means that they were all related to their specific constructs, thereby confirming the posited relationships among the 
indicators and constructs. Secondly, the AVE measure exceeded the cut-off $(0.50)$ - see Fornell and Larcker (1981), for example, for all of the constructs.

Discriminant validity denotes the extent to which any one construct differs from the others. In assessing this, the AVE should be greater than the variance shared between that construct and the other constructs in the model (i.e., the squared correlation between two constructs) (Fornell and Larcker, 1981). The constructs in this study fulfil this condition. In the present model (see Table 1), the diagonal elements (AVEs) are greater than the offdiagonal elements in the corresponding rows and columns. In sum, the model assessments yielded acceptable validity and reliability for the operationalisation of the concepts.

Please insert Table 1 about here

\section{Results}

\section{Correlation Analysis}

Means, standard deviations, and correlations are presented in Table 2. As the matrix shows, there are significant positive correlations between the independent variables (job satisfaction and organisational commitment) and the dependent variables (individual-, unit- and organisation-level performance). This supports the expectation of interconnectedness between job satisfaction, organisational commitment and performance.

Please insert Table 2 about here

\section{Path Analyses}

The research model for job satisfaction used in this study can explain 14\%, 24\% and $27 \%$ of the variance in individual-, unit- and organisation-level performance, respectively (Tables 3 and 4). Organisational commitment can explain $13 \%, 25 \%$ and $32 \%$ of the variance in individual-, unit- and organisation-level performance, respectively. In addition, all values for $\mathrm{Q}^{2}$ (see Tables 3 and 4) are above zero, showing a satisfactory predictive relevance for performance at all levels (Hair et al., 2013). Finally, the effect size $\left(\mathrm{f}^{2}\right)$ values presented in Tables 3 and 4 show that job satisfaction and commitment have between a small and medium effect on performance at the individual level, whereas the effects on both unit- and organisation-level performance are between medium and large (cf. Cohen and Cohen, 1983).

To test the hypotheses, we estimated two path models reflecting the posited relationships between job satisfaction (see Table 3), organisational commitment (see Table 4) and individual-, unit- and organisation-level performance. The path estimates, from job satisfaction to all levels of performance $(\mathrm{H} 1 \mathrm{a}-\mathrm{c})$, were as hypothesised, with a positive impact on perceived individual- $(\mathrm{B}=0.351, \mathrm{p}<0.005)$, unit- $(\mathrm{B}=0.458, \mathrm{p}<0.005)$ and organisationlevel performance $(B=0.517, \mathrm{p}<0.005)$. In addition, confidence intervals $(95 \%)$ have the same outcome (Table 3).

\section{Please insert Table 3 about here}

The predicted paths from organisational commitment to individual-level $(\mathrm{H} 2 \mathrm{a})$, unit-level $(\mathrm{H} 2 \mathrm{~b})$ and organisation-level performance $(\mathrm{H} 2 \mathrm{c})$ were supported by the results. The effect of commitment on perceived performance at the individual- $(B=0.360, p<0.005)$, unit$(\mathrm{B}=0.473, \mathrm{p}<0.005)$ and organisation-level $(\mathrm{B}=0.577, \mathrm{p}<0.005)$ was positive and significant. Again, the confidence intervals (95\%) give additional support for these results (Table 4).

Please insert Table 4 about here 
Next, we tested whether the results were homogeneous in both industries. First, we tested path models differently for both samples (see Hair et al., 2013). Following the guidance of Lowry and Gaskin (2014), we tested whether the path coefficients were significantly different in the two samples. In the job satisfaction model, the only statistically significant $(\mathrm{p}<0.01)$ difference between the samples was in unit-level performance (ICT: $B=0.552$; Forestry: $\mathrm{B}=0.394$ ). In the commitment model, too, there was only one statistically significant ( $\mathrm{p}$ $0.02)$ difference between the samples. The effect on organisation-level performance was stronger in the forestry company $(B=0.618)$ compared with the ICT company $(B=0.484)$. However, in both cases, the direction of the effect was as predicted. It can therefore be argued that there is relative homogeneity between the samples.

\section{Discussion}

Understanding the factors that influence performance is arguably vital for the success of an organisation. From an organisation's perspective, HRM practices are often considered to influence job attitudes and ultimately have a positive impact on individual and organisational performance (Den Hartog et al., 2004). The present study examined the effects of both job satisfaction and organisational commitment on perceived individual-, unit- and organisationlevel performance. Data were collected from employees at an ICT firm and a forestry company in Finland in order to empirically test the suggested model. Six hypotheses were tested. The first set of three hypotheses involved a positive association between job satisfaction and the above-mentioned three levels of performance. The second set postulated a positive association between organisational commitment and performance across the different levels. The results supported all six hypotheses and provide strong empirical support for the hypothesised relationships.

Although a considerable number of studies have been conducted on the effects of job satisfaction and organisational commitment, they concentrate heavily on job performance at the individual-level (Meyer et al., 2008; Riketta, 2008; Saari and Judge, 2004; Crossman and Abou-Zaki, 2003; Porter et al., 1974). In line with previous studies (Judge et al., 2001; Mathieu and Zajac, 1990; Riketta, 2002, 2008), this study showed that organisational commitment and job satisfaction have a modest positive relationship with individual-level job performance. Few previous studies have investigated the relationship between the aggregated level of job attitudes and unit-level (Harter et al., 2002; Conway and Briner, 2012; Den Hartog et al., 2013) or organisational-level performance (Ostroff, 1992; Ryan et al., 1996). The present study adds to this prior work by focusing on individual-level organisational commitment and job satisfaction and by examining their association with employees' perceptions of performance at the individual-, unit- and organisation-level. The main finding of this study was that both organisational commitment and job satisfaction had the strongest positive relationship with perceived organisational-level performance, which supports the present hypotheses. Organisational commitment and job satisfaction were also more strongly related to perceived unit-level performance than to perceived individual-level performance. However, a rather narrow perspective was taken on individual-level job performance by focusing only on task performance. A stronger positive correlation would have been possible if individual-level performance had been explored more broadly - in the form of citizenship behaviour, for example (Saari and Judge, 2002).

This study contributes to the literature by demonstrating that more attention should be paid to the link between employees' work-related attitudes and employees' perceptions about organisation- and unit-level performance. The findings imply that employees who are satisfied with their work and committed to their organisation tend to believe more in their organisation's and their unit's ability to perform well than those who are less satisfied and less committed. However, it should be noted that there is also a possibility for a reversed link 
between job attitudes and perceived performance at different levels. For example, Den Hartog et al. (2004, p. 564) have argued that good organisational performance can lead to the use of more HRM practices in the organisation, which can in turn enhance positive job attitudes among employees.

\section{Managerial Implications}

The data for this study were collected from two large Finnish organisations representing the ICT and forest industries. Both of these sectors have undergone radical change in recent years in Finland, which is likely to have influenced both how the work has been organised and how employees perceive their own performance. Given the commonness of teamwork in organisations today (Rich et al., 2010), it is important to understand the links between employee-level work attitudes and perceptions of unit- and even organisation-level performance. For example, Rich et al. (2010, p. 629) argue that collective engagement can result in "group mind", which can facilitate group- and organisation-level performance. The results of this study demonstrate that both job satisfaction and organisational commitment have a positive effect on employee perceptions of all three performance levels (individual, unit and organisational). The strongest effect is on employees' perceptions of organisationlevel performance and the weakest is on performance at the individual-level. This finding supports the so-called "high-commitment" or "high-involvement" HRM approach, which assumes that work-related attitudes mediate between HRM practices and performance outcomes (Meyer et al., 2008, p. 38). According to the "high-commitment HRM" approach, employees' commitment and job satisfaction can be enhanced by applying so-called "soft HRM practices", such as participation, teamwork, extensive training and multi-skilling (Legge, 2005, p. 209). Den Hartog et al. (2013, p. 1657) argue that HRM practices may play an even more significant role in strengthening the human capital pool for higher-skill jobs compared with lower-skill jobs. Line managers in particular play an important role in terms of "bringing HR policies to life" (Purcell and Hutchinson, 2007, p. 17) and by creating a working environment that encourages positive job attitudes and performance among employees (Den Hartog et al., 2004, p.563). There is also evidence that when managers are satisfied and perform well, it has a positive influence on employees' performance (Netemeyer et al., 2010, p. 542). Based on the present results, efforts to influence employees' job satisfaction and organisational commitment are likely to result in improved performance evaluations by employees. Although many organisations regularly monitor employees' job satisfaction and organisational commitment through wellbeing surveys, such surveys should also assess perceived performance more thoroughly in order to uncover the link between perceived performance levels and work-related attitudes.

\section{Limitations and Further Research}

The data were based on two male-dominated industrial companies in Finland, which limits the generalisability of the results. Therefore, a broader sample covering different gender compositions, occupations and industries is recommended. In addition, further studies could examine job satisfaction, organisational commitment and performance in different cultural contexts, since these issues may vary considerably from country to country (cf. Jaramillo et $a l .$, 2005). Given the data collection methods used in this study (the questionnaires were disseminated by company representatives and returned within a single time period), assessment of non-response bias was not possible in the forestry industry sample.

Based on the literature review, organisational commitment and job satisfaction were hypothesised as antecedents of perceived performance at different levels. However, the crosssectional study design could also suggest the opposite (Ostroff, 1992). Therefore, a longitudinal study is needed in the future. A longitudinal study could also examine how 
individuals' work-related attitudes change over time in order to investigate between-person and within-person variations in such attitudes (Judge and Kammeyer-Mueller, 2012). Although there is evidence that subjective assessments of performance correlate with objective performance data (Wall et al., 2004), incorporating both subjective and objective performance data would enhance an understanding of the relationships between job satisfaction, organisational commitment and performance. In addition, separate rates for job satisfaction and organisational commitment, on the one hand, and performance, on the other, would resolve any possible concerns regarding common method variance. The unit of analysis could also be broadened from the individual to the collective level when analysing workrelated attitudes and their influence on different performance levels (cf. Harter et al., 2002). Using hierarchical multi-level modelling would provide an opportunity to gain deeper insights into the relationship between job satisfaction/organisational commitment and performance at different levels. Future studies could also analyse the possible mediating role of job satisfaction and organisational commitment in the causal chain from HRM practices to organisational performance (cf. Melián-González et al., 2015). In addition, broader concepts, such as job engagement, should be used when investigating the antecedents of performance (cf. Rich et al., 2010). 


\section{References}

Ajzen, I. (1991), "The theory of planned behavior", Organizational Behavior and Human Decision Processes, Vol. 50 No. 2, pp. 179-211.

Armstrong, J.S. and Overton, T.S. (1977), "Estimating nonresponse bias in mail surveys", Journal of Marketing Research, Vol. 14, pp. 396-402.

Bakker, A.B. and Schaufeli, W.B. (2008), "Positive organizational behavior: Engaged employees in flourishing organizations", Journal of Organizational Behavior, Vol. 29 No. 2, pp. 147-154.

Bagozzi, R.P. and Yi, Y. (1991), "Multitrait-multimethod matrices in consumer research", Journal of Consumer Research, Vol. 17 No. 4, pp. 426-439.

Becker, T.E., Billings, R.S., Eveleth, D.M. \& Gilbert, N.L. (1996), "Foci and bases on employee commitment: implications for job performance", Academy of Management Journal, Vol. 39 No. 2, pp. 464-482.

Buchanan II, B. (1974), "Building organizational commitment: The socialization of managers in work organizations", Administrative Science Quarterly, Vol. 19 No. 4, pp. 533-546.

Cohen, J. and Cohen, P. (1983), Applied Multiple Regression/Correlation Analysis for the Behavioral Sciences, 2nd ed., Lawrence Erlbaum Associates, Hillsdale, NJ.

Conway, N. and Briner, R.B. (2012), "Investigating the effect of collective organizational commitment on unit-level performance and absence", Journal of Occupational and Organizational Psychology, Vol. 85 No. 3, pp. 472-486.

Cook, J.D., Hepworth, S.J., Wall, T.D. and Warr, P.B. (1981), The Experience of Work: A Compendium and Review of 249 Measures and Their Use, Academic Press, London.

Cook, J. and Wall, T.D. (1980), "New work attitude measures of trust, organizational commitment, and personal need non-fulfilment", Journal of Occupational Psychology, Vol. 53 No. 1, pp. 39-52.

Crossman, A. and Abou-Zaki, B. (2003), "Job satisfaction and employee performance of Lebanese banking staff", Journal of Managerial Psychology, Vol. 18 No. 4, pp. 368376.

Delaney, J.T. and Huselid, M.A. (1996), "The impact of human resource management practices on perceptions of organizational performance", Academy of Management Journal, Vol. 39 No. 4, pp. 949-969.

Demerouti, E., Xanthopoulou, D., Tsaousis, I. and Bakker, A.B. (2014), "Disentangling task and contextual performance. A multitrait-multimethod approach", Journal of Personnel Psychology, Vol. 13 No. 2, pp. 59-69.

Den Hartog, D.N., Boon, C., Verburg, R.M. and Croon, M.A. (2013), "HRM, communication, satisfaction, and perceived performance: A cross-level test", Journal of Management, Vol. 39 No. 6, pp. 1637-1665.

Den Hartog, D.N., Boselie, P. and Paauwe, J. (2004), "Performance management: A model and research agenda", Applied Psychology: An International Review, Vol. 53 No. 4, $556-569$.

Dessler G. (2008), Human resource management, Pearson, Upper Saddle River, NJ.

Dvir, D. and Shenhar, A. (1992), "Measuring the success of technology-based strategic business units", Engineering Management Journal, Vol. 4 No. 4, pp. 33-38.

Fornell, C. and Larcker, D.F. (1981), "Evaluating structural equation models with unobservable variables and measurement error", Journal of Marketing Research, Vol. 18 No. 1 , pp. 39-50.

Fu, W. and Deshpande, S.P. (2014), "The impact of caring climate, job satisfaction, and organizational commitment on job performance of employees in a China's insurance company, Journal of Business Ethics Vol. 124, Issue 2, pp. 339-349. 
Furtmueller, E., van Dick, R. and Wilderom, C.P.M. (2011), “On the illusion of organizational commitment among finance professionals", Team Performance Management: An International Journal, Vol. 17 No. 5/6, pp. 255-278.

Guillon, O. and Cezanne, C. (2014), "Employee loyalty and organizational performance: A critical survey", Journal of Organizational Change Management, Vol. 27 No. 5, pp. 839-850.

Hair JF, Sarstedt M, Hopkins L, Kuppelwieser VG. (2014). Partial least squares structural equation modeling (PLS-SEM) — an emerging tool in business research. European Business Review 26(2): 106-121.

Hair, J. F., Sarstedt, M., Pieper, T. M., \& Ringle, C. M. (2012). The Use of Partial Least Squares Structural Equation Modeling in Strategic Management Research: A Review of Past Practices and Recommendations for Future Applications. Long Range Planning, 45(5-6), 320-340.

Hair, J. F., Hult, G. T. M., Ringle, C. and Sarstedt, M. (2013). A primer on partial least squares structural equation modeling (PLS-SEM). Sage Publications: Thousand Oaks, CA.

Harter, J.K., Schmidt, F.L. and Hayes, T.L. (2002), "Business-unit-level relationship between employee satisfaction, employee engagement, and business outcomes: A metaanalysis", Journal of Applied Psychology, Vol. 87 No. 2, pp. 268-279.

Hausknecht J.P., Hiller N.J. and Vance R.J. (2008), "Work-unit absenteeism: Effects of satisfaction, commitment, labour market conditions, and time", Academy of Management Journal, Vol. 51 No. 6, pp. 1223-1245.

Hunter, L.W. and Thatcher, S.M.B. (2007), "Feeling the heat: Effects of stress, commitment and job experience on job performance", Academy of Management Journal, Vol. 50 No. 4, pp. 953-968.

Iaffaldano, M.T. and Muchinsky, P.M. (1985), "Job satisfaction and job performance: A meta-analysis", Psychological Bulletin, Vol. 97 No. 2, pp. 251-273.

James, L.R. and Williams, L.J. (2000), "The cross-level operator in regression, ANCOVA, and contextual analysis", in Klein, K.J. and Kozlowski, S.W. (Eds.), Multilevel Theory, Research, and Methods in Organizations, Jossey-Bass, San Francisco, CA, pp. 382-424.

Jaramillo, F., Mulki, J.P. and Marshall, G.W. (2005), “A meta-analysis of the relationship between organizational commitment and salesperson job performance: 25 years of research", Journal of Business Research, Vol. 58 No. 6, pp. 705-714.

Judge, T.A. and Kammeyer-Mueller, J.D. (2012), "Job attitudes", Annual Review of Psychology, Vol. 63 No. 1, pp. 341-367.

Judge, T.A., Thoresen, C.J., Bono, J.E. and Patton, G.K. (2001), “The job satisfaction - job performance relationship: A qualitative and quantitative review", Psychological Bulletin, Vol. 127 No. 3, pp. 376-407.

Kanyurhi, E.B. \& Akonkwa, D.B.M. (2016), "Internal marketing, employee job satisfaction, and perceived organizational performance in microfinance institutions", International Journal of Bank Marketing, Vol. 34 Issue: 5, pp.773-796.

Kaplan, S., Bradley, J.C., Luchman, J.N. and Haynes, D. (2009), "On the role of positive and negative affectivity in job performance: A meta-analytic investigation", Journal of Applied Psychology, Vol. 94 No. 1, pp. 162-176.

Kehoe, R.R. and Wright, P.M. (2013), "The impact of high-performance human resource practices on employees' attitudes and behaviors", Journal of Management, Vol. 39 No. 2, pp. 366-391.

Kinnie, N. and Swart, J. (2009), "Human resource management and organisational performance: In search of the HR advantage", in Redman, T. and Wilkinson, A. 
(Eds.), Contemporary Human Resource Management: Text and Cases, Prentice Hall, Harlow, England, pp. 23-63.

Lee, O.F., Tan, J.A. and Javalgi, R. (2010), "Goal orientation and organizational commitment", International Journal of Organizational Analysis, Vol. 18 No. 1, pp. 129-150.

Legge, K. (2005), Human Resource Management: Rhetorics and Realities (Anniversary Edition), Palgrave, Basingstoke, UK.

Lehto, H. and Sutela, A.M. (2014), “Työolojen muutokset 1977-2013 [Changes in working conditions 1977-2013]," available at: http://www.stat.fi/tup/julkaisut/tiedostot/julkaisuluettelo/ytmv_197713_2014_12309 net.pdf (accessed 17 November 2016).

Liang, H., Saraf, N., Hu, Q. and Zue, Y. (2008), "Assimilation of enterprise systems: The effect of institutional pressures and the mediating role of top management", MIS Quarterly, Vol. 31 No. 1, pp. 59-87.

Lowry, P.B., and Gaskin, J. (2014). 'Partial least squares (PLS) structural equation modeling (SEM) for building and testing behavioral causal theory: When to choose it and how to use it' IEEE Transactions on Professional Communication, 57: 2, 123-146.

Mathews, B.P. and Shepherd, J.L. (2002), “ Dimensionality of Cook and Wall's (1980) British Organizational Commitment Scale revisited", Journal of Occupational and Organizational Psychology, Vol. 75 Issue 3. pp. 369-375.

Mathieu, J.E. and Zajac, D.M. (1990), "A review and meta-analysis of the antecedents, correlates, and consequences of organisational commitment", Psychological Bulletin, Vol. 108 No. 2, pp. 171-194.

Melián-González, S., Bulchand-Gidumal, J. and González López-Valcárcel, B. (2015),” New evidence of the relationship between employee satisfaction and firm economic performance", Personnel Review, Vol. 44 No. 6, pp. 906-929.

Meyer, J.P., Jackson, T.A. and Maltin, E.R. (2008), "Commitment in the workplace: Past, present, and future", in Barling, J. and Cooper, C.L. (Eds.), The SAGE Handbook of Organizational Behavior. Volume 1: Micro Approaches, SAGE Publications, London, UK, pp. 35-53.

Meyer, J.P. and Allen, N.J. (1991), “A three-component conceptualization of organizational commitment”, Human Resource Management Review, Vol. 1 No. 1, pp. 61-89.

Meyer, J.P., Stanley, D.J., Herscovitch, L. and Topolnytsky, L. (2002), “Affective, continuance, and normative commitment to the organization: A meta-analysis of antecedents, correlates, and consequences", Journal of Vocational Behavior, Vol. 61 No. 1, pp. 20-52.

Mowday, R., Steers, R. and Porter, L.W. (1979), "The measurement of organizational commitment", Journal of Vocational Behavior, Vol. 14 No. 2, pp. 224-247.

Mullins L. J. and Christy G. (2016), Management \& organisational behaviour $11^{\text {th }}$ ed. Pearson, Harlow, UK.

Netemeyer, R. G., Maxham III, J.G. and Lichtenstein, D.R. (2010), "Store manager performance and satisfaction: Effects on store employee performance and satisfaction, store customer satisfaction, and store customer spending growth", Journal of Applied Psychology, Vol. 95 No. 3, pp. 530-545.

Ostroff, C. (1992), "The relationship between satisfaction, attitudes, and performance: An organizational level analysis", Journal of Applied Psychology, Vol. 77 No. 6, pp. 963 974.

Podsakoff, P.M., MacKenzie, S.B., Lee, J.-Y. and Podsakoff, N.P. (2003), "Common method biases in behavioral research: A critical review of the literature and recommended remedies", Journal of Applied Psychology, Vol. 88 No. 5, pp. 879-903. 
Porter, L.W., Steers, R.M., Mowday, R.T. and Boulian, P.V. (1974), "Organisational commitment, job satisfaction and turnover among psychiatric technicians", Journal of Applied Psychology, Vol. 59 No. 5, pp. 603-609.

Purcell, J. and Hutchinson, S. (2007), "Front-line managers as agents in the HRMperformance causal chain: Theory, analysis and evidence", Human Resource Management Journal, Vol. 17 No. 1, pp. 3-20.

Qureshi J. A., Hayat K, Ali M. and Sarwat N. (2011), "Impact of job satisfaction and organizational commitment on employee performance: Evidence from Pakistan", Interdisciplinary Journal of Contemporary Research in Business Vol. 3 No. 4, pp. 642-657.

Rich, B.L., Lepine, J.A. and Crawford, E.R. (2010), "Job engagement: Antecedents and effects on job performance", Academy of Management Journal, Vol. 53, No. 3, 617635.

Riketta, M. (2002), "Attitudinal organizational commitment and job performance: A metaanalysis", Journal of Organizational Behavior, Vol. 23 No. 3, pp. 257-266.

Riketta, M. (2008), "The causal relation between job attitudes and performance: A metaanalysis of panel studies", Journal of Applied Psychology, Vol. 93 No. 2, pp. 472-481.

Robinson, R.B. and Pearce, J.A. (1988), "Planned patterns of strategic behaviour and their relationship to business-unit performance", Strategic Management Journal, Vol. 9 No. 1, pp. 43-60.

Robinson, S.L. (1996), "Trust and breach of the psychological contract", Administrative Science Quarterly, Vol. 41 No. 4, pp. 574-599.

Ryan, A.M, Schmit, M.J. and Johnson, R. (1996), "Attitudes and effectiveness: Examining relations at an organizational level", Personnel Psychology, Vol. 49 No. 4, pp. 853882.

Saari, L.M. and Judge, T.A. (2004), "Employee attitudes and job satisfaction”, Human Resource Management, Vol. 43 No. 4, pp. 395-407.

Shaikh, M.A., Bhutto, N.A. and Maitlo, Q. (2012), "Facets of job satisfaction and its association with performance", International Journal of Business and Social Science, Vol. 3 No. 7, pp. 322-326.

Schoemmel, K. and Jønsson, T.S. (2014), "Multiple affective commitments: Quitting intentions and job performance", Employee Relations, Vol. 36 No. 5, pp. 516-534.

Schleicher, D.J., Smith, T.A., Casper, W.J., Watt, J.D. and Greguras, G.J. (2015), "It's all in the attitude: The role of job attitude strength in job attitude-outcome relationships", Journal of Applied Psychology, Vol. 100 No. 4, pp. 1259-1274.

Schneider, B. (1987), "The people make the place", Personnel Psychology, Vol. 40 No. 3 , 437-453.

Siders, M.A., George, G. and Dharwadkar, R. (2001), "The relationship of internal and external commitment foci to objective performance measures", Academy of Management Journal, Vol. 44 No. 3, pp. 570-579.

Siengthai, S. and Pila-Ngarm, P. (2016), "The interaction effect of job redesign and job satisfaction on employee performance", Evidence-based HRM: A Global Forum for Empirical Scholarship, Vol. 4 No 2, pp. 162-180.

Snape, E. and Redman, T. (2010), "HRM practices, organizational citizenship behaviour, and performance: A multi-level analysis", Journal of Management Studies, Vol. 47 No. 7, pp. 1219-1247.

Solinger O.N., van Olffen W. and Roe R.A. (2008), "Beyond the three-component model of organizational commitment", Journal of Applied Psychology, Vol. 93 No. 1, pp. 7083. 
Sonnentag, S., Volmer, J. and Spychala, A. (2008), "Job performance", in Barling, J. and Cooper, C.L. (Eds.), The SAGE Handbook of Organizational Behavior. Volume 1: Micro Approaches, SAGE Publications, London, UK, pp. 427-447.

Wall, T.D., Michie, J., Patterson, M., Wood, S.J., Sheehan, M., Clegg, C.W. and West, M. (2004), "On the validity of subjective measures of company performance", Personnel Psychology, Vol. 51 No. 1, pp. 95-118.

Yiing, L.H. and Bin Ahmad, K.Z. (2009), "The moderating effects of organizational culture on the relationships between leadership behaviour and organizational commitment and between organizational commitment and job satisfaction and performance", Leadership \& Organization Development Journal, Vol. 30 No. 1, pp. 53-86. 


\section{Appendix 1: Measurement Items}

\begin{tabular}{|c|c|c|c|c|}
\hline CONCEPT & ITEM & MEAN & SD & $\begin{array}{l}\text { FACTOR } \\
\text { LOADING }\end{array}$ \\
\hline \multirow{6}{*}{$\begin{array}{l}\text { Job } \\
\text { satisfaction }\end{array}$} & All in all, I am satisfied with: & & & \\
\hline & my manager & 3.87 & 1.05 & $.646^{* * * *}$ \\
\hline & my job & 3.81 & .95 & $.778 * * *$ \\
\hline & $\begin{array}{l}\text { my organisation, compared to } \\
\text { most other organisations }\end{array}$ & 3.46 & 1.04 & $.774 * * *$ \\
\hline & $\begin{array}{l}\text { my career progression in this } \\
\text { organisation so far }\end{array}$ & 3.21 & 1.17 & $.695 * * *$ \\
\hline & $\begin{array}{l}\text { the opportunities I have to } \\
\text { develop myself and move to } \\
\text { new roles in this organisation. }\end{array}$ & 2.97 & 1.14 & $.721 * * *$ \\
\hline \multirow{5}{*}{ Commitment } & $\begin{array}{l}\text { I am quite proud to tell people } \\
\text { what organisation I work for. }\end{array}$ & 3.32 & 1.16 & $.841 * * *$ \\
\hline & $\begin{array}{l}\text { Even if the organisation was not } \\
\text { doing too well financially, I } \\
\text { would be reluctant to move to } \\
\text { another employer. }\end{array}$ & 3.05 & 1.14 & $.603 * * *$ \\
\hline & $\begin{array}{l}\text { In my work, I like to feel I am } \\
\text { making some effort, not just for } \\
\text { myself but for the organisation } \\
\text { as well. }\end{array}$ & 2.70 & 1.30 & $.671 * * *$ \\
\hline & $\begin{array}{l}\text { I would not recommend that a } \\
\text { close friend join this } \\
\text { organisation. }(\mathrm{R})\end{array}$ & 3.12 & 1.30 & $.728 * * *$ \\
\hline & $\begin{array}{l}\text { Knowing that my work has } \\
\text { contributed to the good of the } \\
\text { whole organisation pleases me. }\end{array}$ & 4.03 & .90 & $.668 * * *$ \\
\hline \multirow{3}{*}{$\begin{array}{l}\text { Individual- } \\
\text { level } \\
\text { performance }\end{array}$} & $\begin{array}{l}\text { I am satisfied with my work } \\
\text { performance. }\end{array}$ & 4.14 & .86 & $.801 * * *$ \\
\hline & $\begin{array}{l}\text { My employer is satisfied with } \\
\text { my work performance. }\end{array}$ & 3.96 & .85 & $.843 * * *$ \\
\hline & $\begin{array}{l}\text { I am satisfied with my work } \\
\text { performance compared to that of } \\
\text { other employees who do the } \\
\text { same kind of job. }\end{array}$ & 4.13 & .85 & $.749 * * *$ \\
\hline \multirow{3}{*}{$\begin{array}{l}\text { Unit-level } \\
\text { performance }\end{array}$} & $\begin{array}{l}\text { My unit has achieved its } \\
\text { objectives. }\end{array}$ & 3.84 & .83 & $.639 * * *$ \\
\hline & $\begin{array}{l}\text { My unit has succeeded well } \\
\text { compared to other similar units. }\end{array}$ & 3.95 & .81 & $.660 * * *$ \\
\hline & $\begin{array}{l}\text { My unit has been successful in } \\
\text { advancing and supporting new } \\
\text { business opportunities. }\end{array}$ & 3.55 & .93 & $.777 * * *$ \\
\hline
\end{tabular}




\begin{tabular}{|c|c|c|c|c|}
\hline & $\begin{array}{l}\text { My unit has good prospects in } \\
\text { terms of advancing and } \\
\text { supporting new business } \\
\text { opportunities in the foreseeable } \\
\text { future. }\end{array}$ & 3.62 & .94 & $.789 * * *$ \\
\hline & $\begin{array}{l}\text { My unit's customers and } \\
\text { consumers (both internal and } \\
\text { external) are loyal. }\end{array}$ & 3.47 & .86 & $.672 * * *$ \\
\hline & $\begin{array}{l}\text { My unit has prepared well for } \\
\text { future opportunities and } \\
\text { challenges. }\end{array}$ & 3.41 & 1.01 & $.772 * * *$ \\
\hline & $\begin{array}{l}\text { My unit has the relevant } \\
\text { scientific, technical and } \\
\text { professional knowledge to cope } \\
\text { with future needs. }\end{array}$ & 3.85 & .91 & $.656 * * *$ \\
\hline & $\begin{array}{l}\text { My unit has the relevant } \\
\text { business and consumer } \\
\text { understanding to cope with } \\
\text { future needs. }\end{array}$ & 3.48 & .90 & $.738 * * *$ \\
\hline & Quality of products and services. & 3.76 & .85 & $.633 * * *$ \\
\hline & $\begin{array}{l}\text { Development of new products } \\
\text { and services. }\end{array}$ & 3.61 & .88 & $.666 * * *$ \\
\hline Organisation- & Ability to attract key employees. & 2.90 & .99 & $.783 * * *$ \\
\hline level & Ability to retain key employees. & 2.92 & 1.01 & $.779 * * *$ \\
\hline performance & $\begin{array}{l}\text { Customer/consumer satisfaction } \\
\text { (both internal and external). }\end{array}$ & 3.52 & .77 & $.696 * * *$ \\
\hline & $\begin{array}{l}\text { Relations between management } \\
\text { and employees. }\end{array}$ & 3.13 & 1.03 & $.732 * * *$ \\
\hline
\end{tabular}

Notes: $* * * \mathrm{p}<0.001$. Reverse item is marked with (R). 
Table 1 Discriminant validity

\begin{tabular}{lrrrrr}
\hline & 1 & 2 & 3 & 4 & 5 \\
\hline 1. Job satisfaction & $\mathbf{. 5 3}$ & & & & \\
2. Organizational commitment & $(.85 / . \mathbf{7 8})$ &. $\mathbf{. 5 0}$ & & & \\
3. Individual-level performance & .29 & $(.83 / . \mathbf{6 8})$ & & & \\
& .10 & .06 & $\mathbf{. 6 4}$ & & \\
4. Unit-level performance & .20 & .16 & .10 & $\mathbf{. 5 1}$ & \\
5. Organization-level performance & .25 & .29 & .03 & .30 & $\mathbf{. 5 1}$ \\
& & & & & $(.86 / .81)$ \\
\hline
\end{tabular}

Notes: AVE associated with the construct is presented diagonally. CR and alpha are presented in parentheses. The squared correlations between the constructs are presented in the lower left triangle. AVE = average variance extracted; $\mathrm{CR}=$ composite reliability.

Table 2 Correlation matrix

\begin{tabular}{|c|c|c|c|c|c|c|}
\hline & Mean & $S D$ & 1 & 2 & 3 & 4 \\
\hline 1. Job satisfaction & 3.47 & .78 & & & & \\
\hline $\begin{array}{l}\text { 2. Organizational } \\
\text { commitment }\end{array}$ & 3.25 & .82 & $.535^{* *}$ & & & \\
\hline $\begin{array}{l}\text { 3. Individual-level } \\
\text { performance }\end{array}$ & 4.07 & 69 & $.309 * *$ & $.244 * *$ & & \\
\hline 4. Unit-level performance & 3.64 & .64 & $.449 * *$ & $.396 * *$ & $.311 * *$ & \\
\hline $\begin{array}{l}\text { 5. Organization-level } \\
\text { performance }\end{array}$ & 3.31 & .66 & $.502 * *$ & $.543 * *$ & $.167 * *$ & $.552 * *$ \\
\hline
\end{tabular}

Note: $* * \mathrm{p}<.01$

Table 3 Tested job satisfaction model

\begin{tabular}{|c|c|c|c|c|c|c|}
\hline Path & Path coefficient & t-value & $\begin{array}{c}\text { Confidence } \\
\text { interval } \\
(95 \%)\end{array}$ & $\mathrm{R}^{2}$ & $\mathrm{Q}^{2}$ & $\mathrm{f}^{2}$ \\
\hline \multicolumn{7}{|l|}{ Dependent variables } \\
\hline $\begin{array}{l}\text { Job satisfaction } \rightarrow \text { Individual-level } \\
\text { performance }\end{array}$ & $.351 * * *$ & 9.075 & $.274 ; .428$ & .135 & .08 & .07 \\
\hline Job satisfaction $\rightarrow$ Unit-level performance & $.458 * * *$ & 14.044 & $.396 ; .520$ & .243 & .12 & .26 \\
\hline $\begin{array}{l}\text { Job satisfaction } \rightarrow \text { Organization-level } \\
\text { performance }\end{array}$ & $.517 * * *$ & 17.000 & $.459 ; .575$ & .271 & .14 & .19 \\
\hline \multicolumn{7}{|l|}{ Control variables } \\
\hline Education $\rightarrow$ Individual-level performance & $-.068 *$ & 1.674 & & & & \\
\hline Education $\rightarrow$ Unit-level performance & -.041 n.s. & 1.360 & & & & \\
\hline $\begin{array}{l}\text { Education } \rightarrow \text { Organization-level } \\
\text { performance }\end{array}$ & -.001 n.s. & .043 & & & & \\
\hline $\begin{array}{l}\text { Employment duration } \rightarrow \text { Individual-level } \\
\text { performance }\end{array}$ & .034 n.s. & 1.089 & & & & \\
\hline $\begin{array}{l}\text { Employment duration } \rightarrow \text { Unit-level } \\
\text { performance }\end{array}$ & $.106 * * *$ & 3.105 & & & & \\
\hline $\begin{array}{l}\text { Employment duration } \rightarrow \text { Organization-level } \\
\text { performance }\end{array}$ & -.012 n.s. & 0.469 & & & & \\
\hline Position $\rightarrow$ Individual-level performance & -.039 n.s. & 1.460 & & & & \\
\hline Position $\rightarrow$ Unit-level performance & $.079 *$ & 2.126 & & & & \\
\hline Position $\rightarrow$ Organization-level performance & .036 & 1.397 & & & & \\
\hline
\end{tabular}

Notes: $* \mathrm{p}<0.05 ; * * \mathrm{p}<0.01 ; * * * \mathrm{p}<0.005$ 
Table 4 Tested organizational commitment model

\begin{tabular}{|c|c|c|c|c|c|c|}
\hline Path & Path coefficient & t-value & $\begin{array}{c}\text { Confidence } \\
\text { interval } \\
(95 \%)\end{array}$ & $\mathrm{R}^{2}$ & $\mathrm{Q}^{2}$ & $\mathrm{f}^{2}$ \\
\hline \multicolumn{7}{|l|}{ Dependent variables } \\
\hline Commitment $\rightarrow$ Individual-level performance & $.360 * * *$ & 9.075 & $.265 ; .455$ & .131 & .08 & .06 \\
\hline Commitment $\rightarrow$ Unit-level performance & $.473 * * *$ & 14.044 & $.373 ; .501$ & .247 & .12 & .27 \\
\hline $\begin{array}{l}\text { Commitment } \rightarrow \text { Organization-level } \\
\text { performance }\end{array}$ & $.577 * * *$ & 17.000 & $.526 ; .628$ & .319 & .15 & .28 \\
\hline \multicolumn{7}{|l|}{ Control variables } \\
\hline Education $\rightarrow$ Individual-level performance & $-.122 * *$ & 2.351 & & & & \\
\hline Education $\rightarrow$ Unit-level performance & $-.138 * * *$ & 3.626 & & & & \\
\hline $\begin{array}{l}\text { Education } \rightarrow \text { Organization-level } \\
\text { performance }\end{array}$ & $-.096 * *$ & 2.474 & & & & \\
\hline $\begin{array}{l}\text { Employment duration } \rightarrow \text { Individual-level } \\
\text { performance }\end{array}$ & .065 n.s. & 1.640 & & & & \\
\hline $\begin{array}{l}\text { Employment duration } \rightarrow \text { Unit-level } \\
\text { performance }\end{array}$ & $.161 * * *$ & 4.656 & & & & \\
\hline $\begin{array}{l}\text { Employment duration } \rightarrow \text { Organization-level } \\
\text { performance }\end{array}$ & .022 n.s. & .908 & & & & \\
\hline Position $\rightarrow$ Individual-level performance & -.043 n.s. & 1.493 & & & & \\
\hline Position $\rightarrow$ Unit-level performance & $.077 *$ & 2.227 & & & & \\
\hline Position $\rightarrow$ Organization-level performance & .021 n.s. & 1.043 & & & & \\
\hline
\end{tabular}

Notes: $* \mathrm{p}<0.05 ; * * \mathrm{p}<0.01 ; * * * \mathrm{p}<0.005$ 